

This article appeared in a journal published by Elsevier. The attached copy is furnished to the author for internal non-commercial research and education use, including for instruction at the authors institution and sharing with colleagues.

Other uses, including reproduction and distribution, or selling or licensing copies, or posting to personal, institutional or third party websites are prohibited.

In most cases authors are permitted to post their version of the article (e.g. in Word or Tex form) to their personal website or institutional repository. Authors requiring further information regarding Elsevier's archiving and manuscript policies are encouraged to visit:

http://www.elsevier.com/copyright 


\title{
Sequential ring-closing metathesis-vinyl halide Heck cyclization reactions: access to the tetracyclic ring system of ervitsine
}

\author{
M.-Lluïsa Bennasar*, Ester Zulaica, Daniel Solé, Sandra Alonso \\ Laboratory of Organic Chemistry, Faculty of Pharmacy, and Institut de Biomedicina (IBUB), University of Barcelona, Barcelona 08028, Spain
}

\section{A R T I C L E I N F O}

\section{Article history:}

Received 8 March 2012

Received in revised form 29 March 2012

Accepted 4 April 2012

Available online 19 April 2012

\section{Keywords:}

Alkaloids

Ervitsine

Ring-closing metathesis

Heck cyclization

\begin{abstract}
A B S T R A C T
A chemoselective indole-templated ring-closing metathesis is used to assemble the cyclohepta[b]indole substructure of the indole alkaloid ervitsine. A subsequent intramolecular Heck coupling of the resulting alkene functionality with an amino-tethered vinyl halide accomplishes the closure of the unique 2azabicyclo[4.3.1]decane framework of the alkaloid with concomitant incorporation of the exocyclic Eethylidene substituent.
\end{abstract}

(c) 2012 Elsevier Ltd. All rights reserved.

\section{Introduction}

Ervitsine $^{1}$ is a minor indole alkaloid isolated in 1977 from Pandaca boiteaui (Apocynaceae) ${ }^{2}$ with an unique tetracyclic framework comprising a 2-azabicyclo[4.3.1]decane system fused to the indole ring and two exocyclic alkylidene (16-methylene and 20E-ethylidene) substituents. This complex architecture attracted the synthetic interest of research groups in the eighties and early nineties, resulting in a few approaches to the core structure ${ }^{3,4}$ and a total synthesis based on biomimetic considerations. ${ }^{5}$ Despite the variety of strategies used, all routes have in common the formation of the central carbocyclic ring in the last synthetic steps, either by cyclization of an iminium-type ion upon the indole 3-position (bond formed $\left.C_{5}-C_{7}, \mathbf{a}\right)^{3 a, d, 4,5}$ or by Friedel-Crafts acylation of the indole 2-position (bond formed $\mathrm{C}_{2}-\mathrm{C}_{3}, \mathbf{b}$ ). ${ }^{3 \mathrm{~b}, \mathrm{c}, \mathrm{e}}$

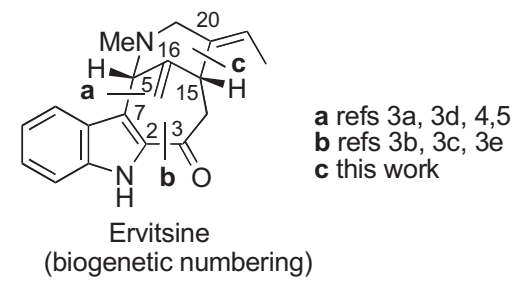

Our long-standing interest in the development of indole annulation methodologies led us to envisage a straightforward synthetic

\footnotetext{
* Corresponding author. Tel./fax: +34 934024540; e-mail address: bennasar@ ub.edu (M.-L. Bennasar).
}

approach to the bridged ervitsine framework relying on an indoletemplated ring-closing metathesis $(\mathrm{RCM})^{6}$ to first construct the central seven-membered ring and a vinyl halide Heck cyclization ${ }^{7}$ to close the piperidine ring and at the same time install the requisite 20E-ethylidene substituent (bond formed $\mathrm{C}_{15}-\mathrm{C}_{20}, \mathbf{c}$ ). ${ }^{8}$ As shown in Scheme 1 , the metathetic ring closure of 2,3dialkenylindoles of general structure $\mathbf{A}$ would provide cyclohepta $[b]$ indoles B, with the appropriate double bond functionality for the subsequent intramolecular Heck reaction with the amino-tethered vinyl halide. ${ }^{9}$ It should be noted that similar Heck couplings of vinyl halides and elaborated cyclohexenes ${ }^{10}$ or cycloheptenes ${ }^{11}$ have proved to be useful for the assembly of the bridged core of several indole alkaloids. In this context, we have successfully explored vinyl halide Heck reactions upon azocine and azonine rings for the total synthesis of apparicine ${ }^{12}$ and cleavamines. ${ }^{13}$

\section{Results and discussion}

To explore the feasibility of the double annulation RCM-Heck methodology for the ervitsine construction, we initially focused on indolic precursors unfunctionalized at the benzylic $\alpha$-position (Scheme $1, Y=H, H$ ), knowing that this methylene group could be oxidized at a later stage of the synthesis. ${ }^{14}$ Thus, cyclohepta[ $\left.b\right]$ indoles 7-9 and 13 were selected as substrates for the key Heck reaction bearing different (carbamate, amine, and amide) exocyclic nitrogen atoms (Scheme 2). The synthetic route began with 2-allyl3-indolecarbaldehyde $\mathbf{1},{ }^{15}$ which was equipped with a strong electron-withdrawing group at the nitrogen to guarantee the stability of the gramine [3-(aminomethyl)indole] moiety of the 


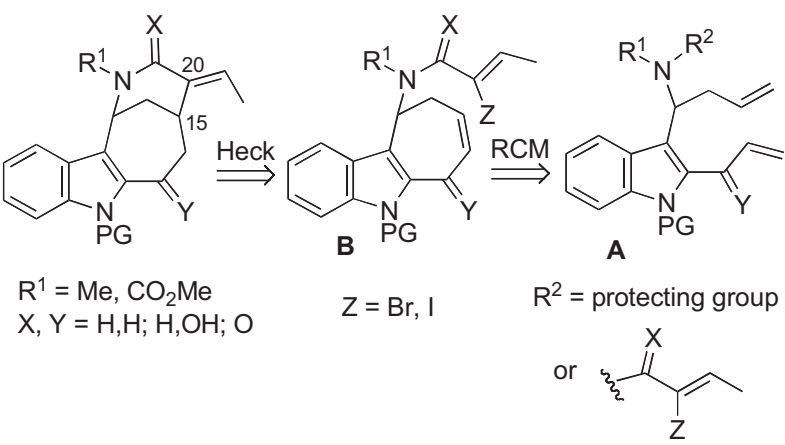

Scheme 1. Synthetic plan.

intermediates. From this compound, an amination-imine allylation sequence was devised to install the homoallylic amine moiety required for the RCM step. We chose a direct route without using protecting groups and incorporated the additional haloalkenyl appendage either at the amination step (for 7-9) or at the final acylation step (for 13), with the hope that it would be sufficiently inert under the RCM conditions. Reaction of aldehyde 1 with (Z)-2bromo-2-butenylamine (2a), followed by alkylation of the resulting imine with allylmagnesium bromide led to the unstable secondary amine 3a (not isolated), which was subsequently acylated with $\mathrm{ClCO}_{2} \mathrm{Me}$ or alkylated with formaldehyde and $\mathrm{NaCNBH}_{3}$ to give carbamate 4 or tertiary amine $\mathbf{6}$ in $60 \%$ and 50\% overall yield, respectively. Starting from 1 and (Z)-2-iodo-2-butenylamine (2b), carbamate $\mathbf{5}$ was similarly prepared in $65 \%$ overall yield through secondary amine $\mathbf{3 b}$. On the other hand, reaction of aldehyde $\mathbf{1}$ with methylamine and allylation of the resulting imine as above gave the unstable secondary amine $\mathbf{1 0}$, which was converted into amide $\mathbf{1 2}$ in $60 \%$ overall yield by acylation with $(Z)$-2-bromo-2-butenoic acid (11) in the presence of 1-ethyl-3-(3-dimethylaminopropyl)carbodiimide (EDC).

At this point we proceeded to study the RCM reaction. Considering the different substitution and electronic nature of the double bonds of the trienic substrates, we expected the preferred RCM event to be the indole-templated cyclization leading to a fused seven-membered ring. Our expectations were confirmed when carbamates $\mathbf{4}$ and $\mathbf{5}$ as well as amide 12, on exposure to the second generation Grubbs catalyst in refluxing $\mathrm{CH}_{2} \mathrm{Cl}_{2}$, gave the desired cycloheptenes $\mathbf{7 , 8}$, and $\mathbf{1 3}$ as the only products in $80 \%, 78 \%$, and $87 \%$ yield, respectively. The tertiary amine 6 was a worse RCM substrate, requiring the previous conversion into the corresponding hydrochloride to afford $\mathbf{9}$ in a slightly lower yield (65\%).

We also sought to elaborate functionalized tricyclic ervitsine substructures $(\mathbf{B}, \mathrm{Y}=\mathrm{H}, \mathrm{OH}$ or $\mathrm{O}$, Scheme 1$)$ but all our efforts met with failure. The simple extension of the chemistry outlined above to an $O$-protected 2-(1-hydroxyallyl)indole such as $\mathbf{1 5}^{\mathbf{1 5}}$ (Scheme 3 ) proved impractical as the formyl group required for the amination-imine allylation step could not be introduced, only complex mixtures being obtained when $\mathbf{1 4}$ was subjected to the Friedel-Crafts protocol $\left(\mathrm{Cl}_{2} \mathrm{CHOMe}, \mathrm{TiCl}_{4}\right)$.

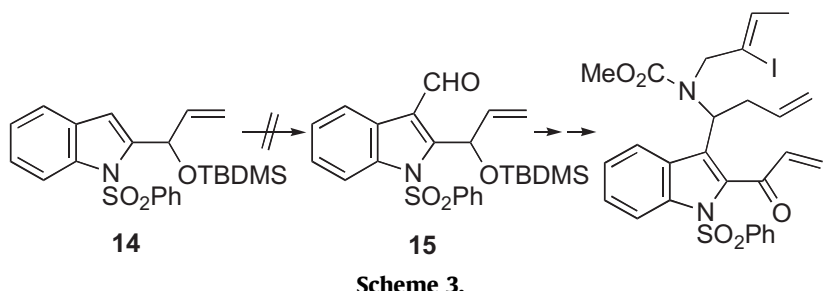

We then planned to install the homoallylic amine moiety on an indole-3-carbaldehyde such as $\mathbf{1 6}^{16}$ or $\mathbf{1 7}^{17}$ before functionalizing the 2-position either by direct metalation or metal-halogen exchange followed by electrophilic trapping (Scheme 4). Given that the base-sensitive halovinyl chain would probably be incompatible with the latter reaction, it would be introduced after the RCM step. Aldehyde 16 was uneventfully converted into carbamate 18 by successive treatment with methylamine, allylmagnesium bromide, and di-tert-butyl dicarbonate, but treatment of this substrate with LDA or alkyl lithium derivatives ( $s$-BuLi, $t$-BuLi) in THF under a variety of experimental conditions, followed by addition of DMF, $\mathrm{HCO}_{2} \mathrm{Me}$, or acrolein, only led to the recovery of the starting material. More satisfactorily, the desired functionalization took place by lithium-halogen exchange from carbamate 19, which was prepared as above from aldehyde 17. Treatment with $t$-BuLi in THF at $-78^{\circ} \mathrm{C}$ followed by quenching with acrolein led to an unstable alcohol, which was immediately oxidized with $\mathrm{MnO}_{2}$ to give ketone 20 in $45 \%$ overall yield. Unfortunately, while RCM of 20 took place in the presence of the second generation Grubbs catalyst in refluxing $\mathrm{CH}_{2} \mathrm{Cl}_{2}$ to give the expected cyclopentenone 21 in $65 \%$ yield (not optimized), all attempts to remove the Boc protecting group for the

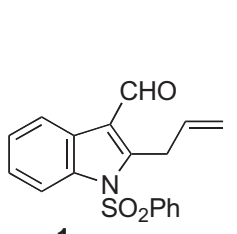

1

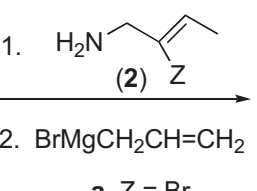

a $\mathrm{Z}=\mathrm{Br}$
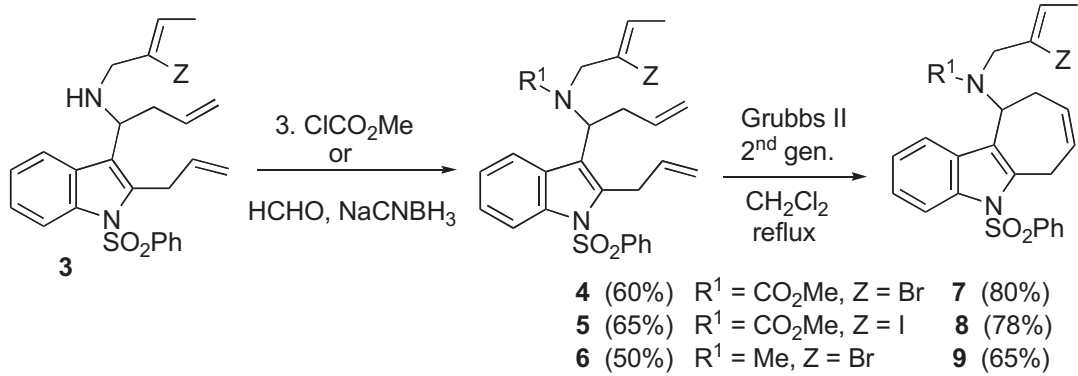<smiles>C=CCc1c(C(CC=C)NC)c2ccccc2n1S(=O)(=O)c1ccccc1</smiles>

10

1. $\mathrm{NH}_{2} \mathrm{CH}_{3}$

2. $\mathrm{BrMgCH}_{2} \mathrm{CH}=\mathrm{CH}_{2}$<smiles>CC=C(Br)C(=O)O</smiles><smiles></smiles>
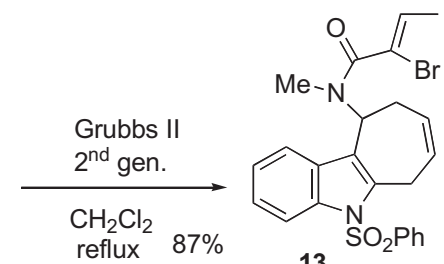

13

Scheme 2. Synthesis of cyclohepta[b]indoles 7-9 and 13. 
subsequent derivatization of the secondary amine invariably led to tropone 22.

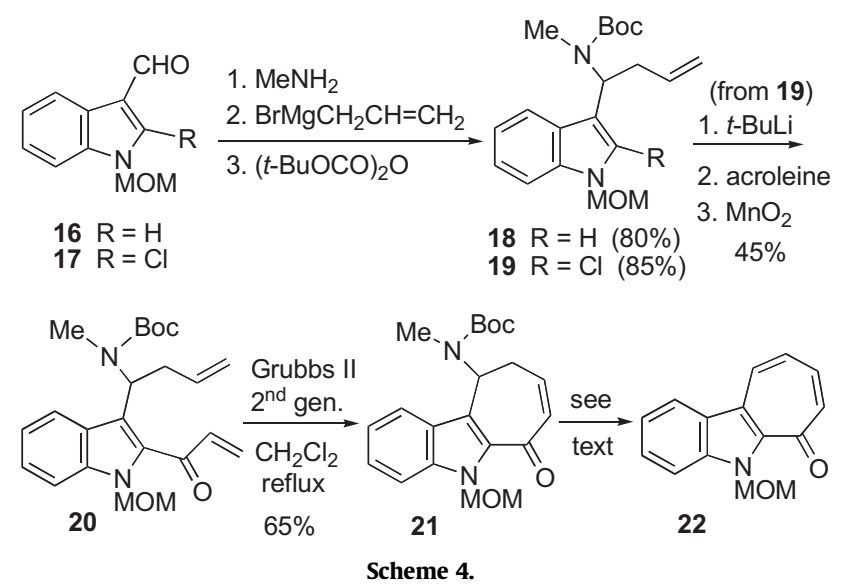

We turned our attention to the intramolecular Heck coupling to complete the bridged framework of ervitsine. Table 1 summarizes the survey of experimental conditions, including palladium precatalysts, ligands, and additives, using carbamates $\mathbf{7}$ and $\mathbf{8}$ as substrates. As can be observed in entry 1 , only the starting product was recovered when vinyl bromide 7 was subjected to classical polar conditions $^{10 \mathrm{a}}\left(\mathrm{Pd}(\mathrm{OAc})_{2}, \mathrm{PPh}_{3}, \mathrm{Et}_{3} \mathrm{~N}, \mathrm{CH}_{3} \mathrm{CN}\right)$. On the other hand, the use of ligand-free conditions introduced by Jeffery ${ }^{18}\left(\mathrm{Pd}(\mathrm{OAc})_{2}\right.$, $\mathrm{K}_{2} \mathrm{CO}_{3}$, TBACl, DMF, entry 2), which had proven successful for the synthesis of related azapolycyclic structures, ${ }^{10 b, c, e}$ resulted in the total decomposition of the material. More successfully, the desired cyclization proceeded upon treatment of $\mathbf{7}$ under non-polar conditions ${ }^{11}$ (palladium catalyst, $\mathrm{PPh}_{3}$, proton sponge, $\mathrm{K}_{2} \mathrm{CO}_{3}$, toluene, entries 3 and 4). However, although the conversion yields were good as evidenced by the NMR analysis of the crude reaction mixtures, the isolated yields of the $(E)$-ethylidene tetracycle $\mathbf{2 3}$ after column chromatography were only moderate (30\%), the starting product being invariably recovered even under longer reaction times.

It should be mentioned that the analogous $N$-methyl derivative 9 (Scheme 5) led to complex reaction mixtures under any of the above Heck conditions. This result seemed to indicate that the presence of a basic nitrogen in the halobutene chain is not compatible with the harsh cyclization conditions, probably due to a competitive dealkylation process. So, unsurprisingly, amide $\mathbf{1 3}$ proved to be a more robust substrate leading to tetracyclic lactam $\mathbf{2 5}$ in $50 \%$ yield.<smiles>C/C=C(/Br)CN(C)C1CC=CCc2c1c1ccccc1n2S(=O)(=O)c1ccccc1</smiles><smiles>CCCCCC(C)(C)C</smiles><smiles></smiles>
9<smiles>C/C=C(/Br)C(=O)N(C)C1CC=CCc2c1c1ccccc1n2S(=O)(=O)c1ccccc1</smiles>
13

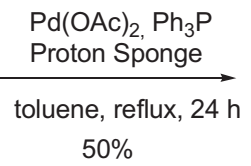<smiles>C/C=C1/C[C@H]2C(OS(=O)(=O)c3ccccc3)=CC[C@H]1/C(=C\C)C(=O)N2C</smiles>

25

Scheme 5. Heck cyclization of $\mathbf{9}$ and $\mathbf{1 3 .}$

We then focused on the more reactive vinyl iodide $\mathbf{8}$. When subjected to the same non-polar protocol (entry 5), tetracycle 23 was obtained only in a slightly better yield (45\%) along with minor amounts of recovered starting product. To increase the efficiency of the process we examined the reaction in the presence of other additives, such as phenol or $\mathrm{Ag}_{2} \mathrm{CO}_{3}$. We were pleased to find that the addition of $20 \mathrm{~mol} \%$ phenol in combination with $\mathrm{K}_{3} \mathrm{PO}_{4}$

Table 1

Heck cyclization of cyclohepta[b]indoles $\mathbf{7}$ and $\mathbf{8}$



\begin{tabular}{|c|c|c|c|}
\hline Entry & Substrate & Reaction conditions & Products (yield \%) \\
\hline 1 & 7 & $\mathrm{Pd}(\mathrm{OAc})_{2}(16 \%), \mathrm{PPh}_{3}$ (50\%), $\mathrm{Et}_{3} \mathrm{~N}$ (2 equiv), $\mathrm{CH}_{3} \mathrm{CN}$, reflux, $3 \mathrm{~h}$ & $7(33)$ \\
\hline 2 & 7 & $\mathrm{Pd}(\mathrm{OAc})_{2}(5 \%), \mathrm{K}_{2} \mathrm{CO}_{3}$ ( 5 equiv), TBACl ( 1 equiv), DMF, $60^{\circ} \mathrm{C}, 4 \mathrm{~h}$ & -- \\
\hline 3 & 7 & $\mathrm{Pd}(\mathrm{OAc})_{2}(5 \%), \mathrm{PPh}_{3}(20 \%)$, proton sponge (0.5 equiv), $\mathrm{K}_{2} \mathrm{CO}_{3}$ ( 1.1 equiv), toluene, reflux, $4 \mathrm{~h}$ & $\begin{array}{l}23(30) \\
7(16)\end{array}$ \\
\hline 4 & 7 & $\mathrm{Pd}\left(\mathrm{PPh}_{3}\right)_{4}(5 \%)$, proton sponge ( 0.1 equiv), $\mathrm{K}_{2} \mathrm{CO}_{3}$ (2.5 equiv), toluene, sealed tube, 2.5 days & $\begin{array}{l}23(30) \\
7(5)\end{array}$ \\
\hline 5 & 8 & $\mathrm{Pd}(\mathrm{OAc})_{2}(10 \%), \mathrm{PPh}_{3}$ (40\%), proton sponge ( 0.3 equiv), $\mathrm{K}_{2} \mathrm{CO}_{3}$ ( 1.5 equiv), toluene, reflux, $24 \mathrm{~h}$ & $\begin{array}{l}23(45) \\
\mathbf{8}(10)\end{array}$ \\
\hline 6 & 8 & $\mathrm{Pd}\left(\mathrm{PPh}_{3}\right)_{4}(10 \%), \mathrm{K}_{3} \mathrm{PO}_{4}$ ( 3 equiv), $\mathrm{Et}_{3} \mathrm{~N}$ (6 equiv), phenol ( 0.2 equiv), toluene, reflux, $12 \mathrm{~h}$ & $23(65)$ \\
\hline 7 & 8 & $\mathrm{Pd}(\mathrm{OAc})_{2}(10 \%), \mathrm{PPh}_{3}(30 \%), \mathrm{Ag}_{2} \mathrm{CO}_{3}$ (3 equiv), toluene, reflux, $40 \mathrm{~min}$ & $\begin{array}{l}23(45) \\
24(15)\end{array}$ \\
\hline 8 & 8 & $\mathrm{Pd}(\mathrm{OAc})_{2}(10 \%), \mathrm{PPh}_{3}(30 \%), \mathrm{Ag}_{2} \mathrm{CO}_{3}$ (3 equiv), toluene, $80{ }^{\circ} \mathrm{C}, 1 \mathrm{~h}$ & $\begin{array}{l}23(19) \\
24(43)\end{array}$ \\
\hline 9 & 8 & $\mathrm{Pd}(\mathrm{OAc})_{2}(10 \%)$, dppe (12\%), $\mathrm{Ag}_{2} \mathrm{CO}_{3}$ ( 3 equiv), DIPEA ( 2 equiv), toluene, reflux, $2 \mathrm{~h}$ & $\begin{array}{l}23(25) \\
24(25)\end{array}$ \\
\hline
\end{tabular}

${ }^{\text {a }}$ Isolated yields after column chromatography. 
resulted in a cleaner cyclization, giving the ervitsine tetracycle $\mathbf{2 3}$ as the only product in 65\% yield (entry 6). As far as we know, the use of phenol as a catalytic additive in the Heck reaction is unprecedented, although its positive role in some palladiumcatalyzed arylations of ketone enolates has been previously observed. ${ }^{19,20}$ According to these reports, ${ }^{19}$ the intermediacy of a palladium phenoxide (e.g., C), which would stabilize an otherwise unstable intermediate, could account for the beneficial effect of the added phenol.

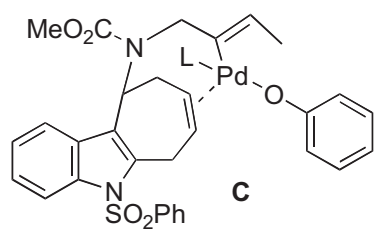

On the other hand, although the starting material was rapidly consumed in the presence of $\mathrm{Ag}_{2} \mathrm{CO}_{3}$ (entries 7-9), the cyclization followed a different course as it led to mixtures of tetracycles $\mathbf{2 3}$ and 24, the latter coming from an apparent 7-endo cyclization with inversion of the ethylidene configuration. ${ }^{21}$ Tetracycle $\mathbf{2 3}$ was the major product when the reaction was carried out in refluxing toluene (entry 7) while the formation of the abnormal product $\mathbf{2 4}$ was enhanced by working at lower temperatures (entry 8 ) or changing the ligand from $\mathrm{Ph}_{3} \mathrm{P}$ to dppe (entry 9).

The formation of unusual Heck cyclization products like 24 has been previously observed ${ }^{12 b, 22}$ and rationalized ${ }^{23}$ by considering that the initial 6-exo cyclization is not followed by the expected $\beta$-hydride elimination (which would lead to 23 ) but by an intramolecular carbopalladation on the exocyclic alkene. The resulting cyclopropane intermediate would undergo rearrangement, with concomitant inversion of the alkene geometry, and final $\beta$-hydride elimination. In our case, the competitive formation of $\mathbf{2 4}$ is only observed in the presence of $\mathrm{Ag}_{2} \mathrm{CO}_{3}$, probably because under these cationic conditions the benzenesulfonyl group is able to weakly coordinate with the initially formed cationic $\sigma$-alkyl palladium intermediate to give a sevenmembered palladacycle ${ }^{24}$ (Scheme 6 ). The $\beta$-hydride elimination would thus be partially prevented and the intramolecular cyclopropanation route favored, in particular when the reaction is performed at a relatively low temperature or in the presence of a chelating phosphine such as dppe.

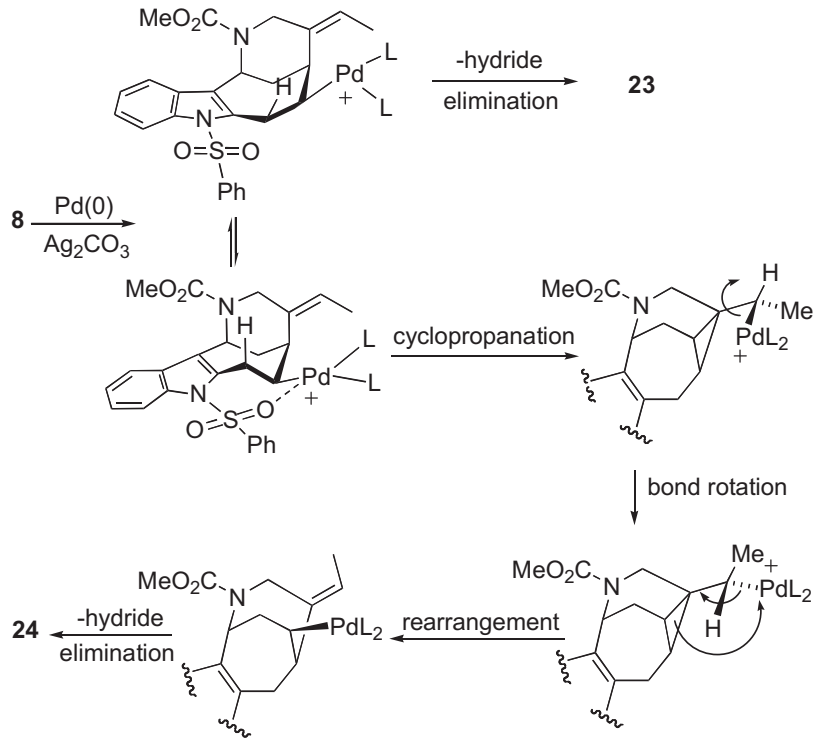

Scheme 6.

\section{Conclusions}

We have succeeded in synthesizing tetracycles $\mathbf{2 3}$ and $\mathbf{2 5}$, which embody the $4 E$-ethylidene-2-azabicyclo[4.3.1]decane bridged core of the indole alkaloid ervitsine, using a combination of an indoletemplated RCM and a vinyl halide Heck cyclization. This result highlights the power of the double annulation RCM-Heck methodology for rapidly building up the highly complex structure present in some indole alkaloids.

\section{Experimental section}

\subsection{General}

All nonaqueous reactions were carried out under an argon atmosphere. All solvents were dried by standard methods. Reaction courses and product mixtures were routinely monitored by TLC on $\mathrm{SiO}_{2}$ (silica gel $60 \mathrm{~F}_{254}$ ) and the spots were located with aqueous potassium permanganate solution. Drying of organic extracts was carried out over anhydrous $\mathrm{Na}_{2} \mathrm{SO}_{4}$. The solvents were evaporated under reduced pressure with a rotary evaporator. Column chromatography was carried out using the flash chromatography technique on $\mathrm{SiO}_{2}$ (silica gel 60, SDS, 0.04-0.06 mm). NMR spectra were recorded in $\mathrm{CDCl}_{3}$ using $\mathrm{Me}_{4} \mathrm{Si}$ as an internal reference. HRMS were obtained using an LC/MSD TOF mass spectrometer.

\subsection{Synthesis of the RCM substrates}

4.2.1. (Z)-2-Bromo-2-butenylamine (2a). (Z)-1,2-dibromo-2-butene ${ }^{25}$ $(3.12 \mathrm{~g}, 14.6 \mathrm{mmol})$ was added dropwise $(1 \mathrm{~h})$ to a solution of hexamethylenetetramine $(2.25 \mathrm{~g}, 16 \mathrm{mmol})$ in $\mathrm{CHCl}_{3}(18 \mathrm{~mL})$ heated at reflux. The resulting mixture was heated at reflux for $4 \mathrm{~h}$ and then allowed to stand in the refrigerator overnight. The mixture was cooled in an ice bath and the quaternary salt was collected by filtration. The crude salt was dissolved in a warm solution, prepared from $\mathrm{H}_{2} \mathrm{O}(6 \mathrm{~mL}), \mathrm{EtOH}(29 \mathrm{~mL})$, and $37 \% \mathrm{HCl}(8 \mathrm{~mL})$. The mixture was stirred for $4 \mathrm{~h}$ and then allowed to stand overnight. A precipitate of $\mathrm{NH}_{4} \mathrm{Cl}$ was formed, which was removed by filtration, washing carefully with ethanol. The filtrate was concentrated to a quarter of the volume and the resulting solid was removed by filtration. The filtrate was concentrated to dryness and the solid residue was carefully dried. The residue was digested with $\mathrm{MeOH}(15 \mathrm{~mL})$ and the resulting solid was removed by filtration. The filtrate was concentrated to dryness to give 2a hydrochloride ( $2.75 \mathrm{~g}$, quantitative), which was used in the next reaction without purification.

4.2.2. 2-Allyl-3-[1-[N-(Z)-(2-bromo-2-butenyl)- $N$-(methoxycarbonyl)amino]-3-butenyl]-1-(phenylsulfonyl)indole (4). $\mathrm{Et}_{3} \mathrm{~N}(0.31 \mathrm{~mL}, 2.23$ $\mathrm{mmol}$ ) was added to a solution of amine $\mathbf{2 a}$ hydrochloride $(0.29 \mathrm{~g}$, $1.5 \mathrm{mmol})$ in $\mathrm{CH}_{2} \mathrm{Cl}_{2}(5 \mathrm{~mL})$ and the mixture was stirred at $\mathrm{rt}$ for $10 \mathrm{~min}$. Aldehyde $\mathbf{1}^{15}(0.34 \mathrm{~g}, 1.0 \mathrm{mmol})$ in $\mathrm{CH}_{2} \mathrm{Cl}_{2}(5 \mathrm{~mL})$ and $\mathrm{AcOH}$ $(0.06 \mathrm{~mL}, 1.0 \mathrm{mmol})$ were successively added and the resulting mixture was stirred at $\mathrm{rt}$ for $18 \mathrm{~h}$. The reaction mixture was diluted with $\mathrm{CH}_{2} \mathrm{Cl}_{2}(5 \mathrm{~mL})$, basified with a saturated aqueous $\mathrm{Na}_{2} \mathrm{CO}_{3}$ solution $(10 \mathrm{~mL})$, and extracted with $\mathrm{CH}_{2} \mathrm{Cl}_{2}(2 \times 10 \mathrm{~mL})$. The organic extracts were dried and concentrated to give the crude imine $(480 \mathrm{mg})$. Allylmagnesium bromide ( $1 \mathrm{M}$ in $\mathrm{Et}_{2} \mathrm{O}, 1.6 \mathrm{~mL}, 1.6 \mathrm{mmol}$ ) was added under $\mathrm{Ar}$ to a cooled $\left(-78^{\circ} \mathrm{C}\right)$ solution of the above imine in anhydrous THF $(30 \mathrm{~mL})$, and the resulting mixture was stirred at $\mathrm{rt}$ for $2 \mathrm{~h}$. The reaction mixture was quenched with a $10 \%$ aqueous $\mathrm{NH}_{4} \mathrm{Cl}$ solution $(5 \mathrm{~mL})$ and extracted with $\mathrm{Et}_{2} \mathrm{O}(3 \times 10 \mathrm{~mL})$. The ethereal extracts were dried and concentrated to give the crude amine 3a (342 mg). A solution of the above amine $3 a$ in anhydrous THF (12 mL) was added under Ar to a suspension of $\mathrm{NaH}(60 \%, 56 \mathrm{mg}, 1.4 \mathrm{mmol})$ in THF $(2 \mathrm{~mL})$ cooled at $-20^{\circ} \mathrm{C}$, and the mixture was stirred at $-20^{\circ} \mathrm{C}$ for $20 \mathrm{~min}$. A solution of $\mathrm{ClCO}_{2} \mathrm{Me}(0.16 \mathrm{~mL}, 2.1 \mathrm{mmol})$ in THF $(1 \mathrm{~mL})$ 
was then added and the mixture was stirred at rt overnight. The reaction mixture was quenched with $\mathrm{H}_{2} \mathrm{O}(10 \mathrm{~mL})$ and extracted with $\mathrm{Et}_{2} \mathrm{O}(2 \times 15 \mathrm{~mL})$. The combined organic extracts were dried and concentrated. The resulting residue was chromatographed (97:3 hexanes/AcOEt) to give bromo triene $\mathbf{4}$ as a light brown oil: ( $0.35 \mathrm{~g}$, $60 \%) ;{ }^{1} \mathrm{HNMR}(400 \mathrm{MHz}) \delta 1.40(\mathrm{~d}, J=6.4 \mathrm{~Hz}, 3 \mathrm{H}), 2.90(\mathrm{~m}, 2 \mathrm{H}), 3.72(\mathrm{~s}$, $3 \mathrm{H}), 3.89(\mathrm{~m}, 2 \mathrm{H}), 3.96(\mathrm{br} \mathrm{s}, 2 \mathrm{H}), 4.95(\mathrm{~m}, 2 \mathrm{H}), 5.03(\mathrm{~m}, 2 \mathrm{H}), 5.41(\mathrm{q}$, $J=6.4 \mathrm{~Hz}, 1 \mathrm{H}), 5.56(\mathrm{~m}, 1 \mathrm{H}), 5.60(\mathrm{~m}, 1 \mathrm{H}), 5.96(\mathrm{~m}, 1 \mathrm{H}), 7.26(\mathrm{~m}, 2 \mathrm{H})$, $7.41(\mathrm{~m}, 2 \mathrm{H}), 7.53(\mathrm{~m}, 1 \mathrm{H}), 7.66(\mathrm{~d}, J=8.0 \mathrm{~Hz}, 1 \mathrm{H}), 7.73(\mathrm{~m}, 2 \mathrm{H}), 8.21$ $(\mathrm{dm}, J=8.0 \mathrm{~Hz}, 1 \mathrm{H}) ;{ }^{13} \mathrm{C} \mathrm{NMR}(74.5 \mathrm{MHz}) \delta 16.1\left(\mathrm{CH}_{3}\right), 30.2\left(\mathrm{CH}_{2}\right), 36.9$ $\left(\mathrm{CH}_{2}\right), 51.4\left(\mathrm{CH}_{2}\right), 52.9\left(\mathrm{CH}_{3}\right), 53.2(\mathrm{CH}), 115.1(\mathrm{CH}), 116.3\left(\mathrm{CH}_{2}\right), 117.5$ $\left(\mathrm{CH}_{2}\right), 118.8(\mathrm{C}), 120.1(\mathrm{CH}), 123.2(\mathrm{CH}), 123.6(\mathrm{CH}), 124.2(\mathrm{CH}), 124.3$ (C), $126.4(2 \mathrm{CH}), 129.2(2 \mathrm{CH}), 129.4(\mathrm{C}), 133.7(\mathrm{CH}), 134.4(\mathrm{CH}), 134.8$ (CH), 136.5 (C), 138.3 (C), 138.9 (C), 156.6 (CO); ESI-HRMS [M+H] calcd for $\mathrm{C}_{27} \mathrm{H}_{30} \mathrm{BrN}_{2} \mathrm{O}_{4} \mathrm{~S}$ 557.1110, found 557.1104.

4.2.3. 2-Allyl-3-[1-[N-(Z)-(2-iodo-2-butenyl)-N-(methoxycarbonyl) amino]-3-butenyl]-1-(phenylsulfonyl)indole (5). Operating as above, from aldehyde $\mathbf{1}^{15}(0.20 \mathrm{~g}, 0.6 \mathrm{mmol})$ and the amine $2 \mathbf{b}$ hydrochloride $^{26}(0.25 \mathrm{~g}, 1.0 \mathrm{mmol})$, carbamate $\mathbf{5}$ was obtained as a light brown oil: $0.24 \mathrm{~g}(65 \%) ;{ }^{1} \mathrm{H}$ NMR $(400 \mathrm{MHz}) \delta 1.30$ (d, J=6.4 Hz, 3H), $2.82(\mathrm{~m}, 2 \mathrm{H}), 3.63(\mathrm{~s}, 3 \mathrm{H}), 3.81(\mathrm{~m}, 2 \mathrm{H}), 3.90$ and $3.95(2 \mathrm{~d}, J=16 \mathrm{~Hz}$, $2 \mathrm{H}), 4.82(\mathrm{~d}, J=10.4 \mathrm{~Hz}, 1 \mathrm{H}), 4.90(\mathrm{br} \mathrm{s}, 1 \mathrm{H}), 4.95(\mathrm{~m}, 2 \mathrm{H}), 5.18(\mathrm{q}$, $J=6.4 \mathrm{~Hz}, 1 \mathrm{H}), 5.47(\mathrm{~m}, 2 \mathrm{H}), 5.90(\mathrm{~m}, 1 \mathrm{H}), 7.16(\mathrm{~m}, 2 \mathrm{H}), 7.30(\mathrm{~m}, 2 \mathrm{H})$, $7.42(\mathrm{~m}, 1 \mathrm{H}), 7.58(\mathrm{dm}, J=8 \mathrm{~Hz}, 1 \mathrm{H}), 7.65(\mathrm{~m}, 2 \mathrm{H}), 8.12(\mathrm{~d}, J=7.8 \mathrm{~Hz}$, $1 \mathrm{H}) ;{ }^{13} \mathrm{C}$ NMR $(400 \mathrm{MHz}) \delta 21.3\left(\mathrm{CH}_{3}\right), 30.4\left(\mathrm{CH}_{2}\right), 36.7(\mathrm{CH}), 52.9$ $\left(\mathrm{CH}_{3}\right), 53.2(\mathrm{CH}), 54.7\left(\mathrm{CH}_{2}\right), 105.5(\mathrm{C}), 115.0(\mathrm{CH}), 116.3\left(\mathrm{CH}_{2}\right), 117.6$ $\left(\mathrm{CH}_{2}\right), 118.7(\mathrm{C}), 120.2(\mathrm{CH}), 123.7(\mathrm{CH}), 124.2(\mathrm{CH}), 126.4(2 \mathrm{CH})$, 129.0 (CH), $129.2(2 \mathrm{CH}), 129.3(\mathrm{C}), 133.8(\mathrm{CH}), 134.4(\mathrm{CH}), 134.9(\mathrm{CH})$, 136.4 (C), 138.2 (C), 138.9 (C), $156.6(\mathrm{CO})$.

4.2.4. 2-Allyl-3-[1-[N-(Z)-(2-bromo-2-butenyl)-N-methylamino]-3butenyl]-1-(phenylsulfonyl)indole (6). Aldehyde $\mathbf{1}^{15}$ (0.17 g, $0.5 \mathrm{mmol}$ ) was allowed to react with 2a hydrochloride and allylmagnesium bromide as described for the preparation of carbamate 4. The resulting crude amine $3 a(170 \mathrm{mg})$ was dissolved in $\mathrm{CH}_{3} \mathrm{CN}$ $(1.5 \mathrm{~mL})$ and the resulting solution was treated with $37 \%$ aqueous formaldehyde $\left(1.7 \mathrm{mmol}\right.$ ) and $\mathrm{NaBH}_{3} \mathrm{CN}(34 \mathrm{mg}, 0.55 \mathrm{mmol})$ for $45 \mathrm{~min}$ at $\mathrm{rt}$. The acidic $\mathrm{pH}$ was maintained with regular addition of $\mathrm{AcOH}$. The reaction mixture was basified with $2 \mathrm{~N} \mathrm{NaOH}(5 \mathrm{~mL})$, diluted with $\mathrm{H}_{2} \mathrm{O}(10 \mathrm{~mL})$, and extracted with $\mathrm{Et}_{2} \mathrm{O}(3 \times 10 \mathrm{~mL})$. The organic layer was washed with $2 \mathrm{~N} \mathrm{NaOH}(2 \times 10 \mathrm{~mL})$, dried, and concentrated. The resulting residue was chromatographed (90:10 hexanes/AcOEt) to give 6 as a light brown oil: $134 \mathrm{mg}(50 \%) ;{ }^{1} \mathrm{H}$ $\operatorname{NMR}(400 \mathrm{MHz}) \delta 1.71(\mathrm{~d}, J=6.4 \mathrm{~Hz}, 3 \mathrm{H}), 2.11(\mathrm{~s}, 3 \mathrm{H}), 2.58(\mathrm{~m}, 1 \mathrm{H})$, $2.76(\mathrm{~m}, 1 \mathrm{H}), 3.11(\mathrm{br} \mathrm{s}, 2 \mathrm{H}), 3.54(\mathrm{dd}, J=9.6$ and $4.8 \mathrm{~Hz}, 1 \mathrm{H}), 3.82(\mathrm{~m}$, $2 \mathrm{H}), 4.63(\mathrm{~d}, J=9.6 \mathrm{~Hz}, 1 \mathrm{H}), 4.72(\mathrm{~d}, J=18.4 \mathrm{~Hz}, 1 \mathrm{H}), 5.07(\mathrm{~m}, 2 \mathrm{H}), 5.20$ (m, 1H), $5.86(\mathrm{q}, J=6.4 \mathrm{~Hz}, 1 \mathrm{H}), 5.99(\mathrm{~m}, 1 \mathrm{H}), 7.20(\mathrm{~m}, 1 \mathrm{H}), 7.24(\mathrm{~m}$, $1 \mathrm{H}), 7.32(\mathrm{~m}, 2 \mathrm{H}), 7.46(\mathrm{~m}, 1 \mathrm{H}), 7.61(\mathrm{~m}, 2 \mathrm{H}), 7.91(\mathrm{~d}, J=7.6 \mathrm{~Hz}, 1 \mathrm{H})$, $8.17(\mathrm{~d}, J=8.4 \mathrm{~Hz}, 1 \mathrm{H}) ;{ }^{13} \mathrm{C}$ NMR $(74.5 \mathrm{MHz}) \delta 16.6\left(\mathrm{CH}_{3}\right), 30.6\left(\mathrm{CH}_{2}\right)$, $37.0\left(\mathrm{CH}_{2}\right), 39.6\left(\mathrm{CH}_{3}\right), 61.7(\mathrm{CH}), 63.8\left(\mathrm{CH}_{2}\right), 115.2(\mathrm{CH}), 116.4\left(\mathrm{CH}_{2}\right)$, $116.7\left(\mathrm{CH}_{2}\right), 121.7(\mathrm{CH}), 122.6(\mathrm{C}), 123.5(\mathrm{CH}), 124.4(\mathrm{CH}), 125.6(\mathrm{CH})$, 126.2 (2CH), $126.8(\mathrm{C}), 128.9(2 \mathrm{CH}), 129.4(\mathrm{C}), 133.4(\mathrm{CH}), 135.2(\mathrm{CH})$, $135.3(\mathrm{CH}), 136.0(\mathrm{C}), 137.1(\mathrm{C}), 138.6(\mathrm{C})$; ESI-HRMS $[\mathrm{M}+\mathrm{H}]^{+}$calcd for $\mathrm{C}_{26} \mathrm{H}_{30} \mathrm{BrN}_{2} \mathrm{O}_{2} \mathrm{~S}$ 513.1205, found 513.1200.

4.2.5. 2-Allyl-3-[1-(Z)-(2-bromo-N-methyl-2-butenamido)-3butenyl-1-(phenylsulfonyl)indole (12). Methylamine (8 $\mathrm{M}$ in EtOH, $1.9 \mathrm{~mL}, 15 \mathrm{mmol})$ and $\mathrm{AcOH}(0.09 \mathrm{~mL}, 1.5 \mathrm{mmol})$ were successively added to a solution of aldehyde $1(0.5 \mathrm{~g}, 1.5 \mathrm{mmol})$ in $\mathrm{CH}_{2} \mathrm{Cl}_{2}$ $(15 \mathrm{~mL})$. After being stirred at rt overnight, the reaction mixture was diluted with $\mathrm{CH}_{2} \mathrm{Cl}_{2}(10 \mathrm{~mL})$, basified with a saturated $\mathrm{Na}_{2} \mathrm{CO}_{3}$ solution and extracted with $\mathrm{CH}_{2} \mathrm{Cl}_{2}(3 \times 10 \mathrm{~mL})$. The organic extracts were dried and concentrated to give the crude imine: $0.5 \mathrm{~g}$. Allylmagnesium bromide ( $1 \mathrm{M}$ in $\mathrm{Et}_{2} \mathrm{O}, 2.4 \mathrm{~mL}, 2.4 \mathrm{mmol}$ ) was added under $\mathrm{Ar}$ to a cooled $\left(-78^{\circ} \mathrm{C}\right)$ solution of the above imine in anhydrous THF (30 mL), and the resulting mixture was stirred at $\mathrm{rt}$ overnight. The reaction mixture was quenched with a $10 \%$ aqueous $\mathrm{NH}_{4} \mathrm{Cl}$ solution $(10 \mathrm{~mL})$ and extracted with $\mathrm{Et}_{2} \mathrm{O}(3 \times 15 \mathrm{~mL})$. The ethereal extracts were dried and concentrated to give the crude amine 10 (0.5 g). Butenoic acid $11^{27}(0.49 \mathrm{~g}, 3 \mathrm{mmol})$ and 1-ethyl-3(3-dimethylaminopropyl)carbodiimide (EDC, $0.46 \mathrm{~g}, 3 \mathrm{mmol}$ ) were added to a solution of the above amine 10 in $\mathrm{CH}_{2} \mathrm{Cl}_{2}(30 \mathrm{~mL})$ and the mixture was stirred at $\mathrm{rt}$ for 2.5 days. The reaction mixture was diluted with $\mathrm{CH}_{2} \mathrm{Cl}_{2}(10 \mathrm{~mL})$ and washed with $1.5 \mathrm{M}$ aqueous $\mathrm{HCl}$ $(2 \times 10 \mathrm{~mL})$ and aqueous $10 \% \mathrm{NaOH}(2 \times 10 \mathrm{~mL})$. The resulting organic solution was dried and concentrated and the resulting residue was chromatographed (95:5 hexanes/AcOEt) to give the title compound 12 as a pale yellow foam: $0.48 \mathrm{~g}(60 \%) ;{ }^{1} \mathrm{H}$ NMR $(400 \mathrm{MHz}) \delta 1.90(\mathrm{~d}$, $J=6.6 \mathrm{~Hz}, 3 \mathrm{H}), 2.77\left(\mathrm{~s}, 3 \mathrm{H}, \mathrm{NCH}_{3}\right), 2.90(\mathrm{~m}, 2 \mathrm{H}), 3.90(\mathrm{~m}, 2 \mathrm{H}), 5.00$ (m, 4H), $5.70(\mathrm{~m}, 1 \mathrm{H}), 5.95(\mathrm{~m}, 2 \mathrm{H}), 6.05(\mathrm{q}, J=6.6 \mathrm{~Hz}, 1 \mathrm{H}), 7.20(\mathrm{~m}$, $2 \mathrm{H}), 7.38(\mathrm{~m}, 2 \mathrm{H}), 7.50(\mathrm{~m}, 1 \mathrm{H}), 7.70(\mathrm{~m}, 3 \mathrm{H}), 8.25(\mathrm{~d}, J=8 \mathrm{~Hz}, 1 \mathrm{H}) ;{ }^{13} \mathrm{C}$ NMR $(74.5 \mathrm{MHz}) \delta 16.3\left(\mathrm{CH}_{3}\right), 30.1\left(\mathrm{CH}_{2}\right), 34.9\left(\mathrm{CH}_{2}\right), 32.3\left(\mathrm{CH}_{3}\right)$, $50.2(\mathrm{CH}), 115.5(\mathrm{CH}), 116.2\left(\mathrm{CH}_{2}\right), 117.6(\mathrm{C}), 117.7\left(\mathrm{CH}_{2}\right), 120.1(\mathrm{CH})$, $123.8(\mathrm{CH}), 124.2(\mathrm{CH}), 126.3(2 \mathrm{CH}), 127.0(\mathrm{C}), 129.1(2 \mathrm{CH}), 129.3$ (CH), $133.7(\mathrm{CH}), 134.0(\mathrm{CH}), 135.1(\mathrm{CH}), 135.2(\mathrm{C}), 136.8(\mathrm{C}), 138.5$ (C), 138.9 (C), 166.3 (CO); ESI-HRMS $[\mathrm{M}+\mathrm{H}]^{+}$calcd for $\mathrm{C}_{26} \mathrm{H}_{28} \mathrm{BrN}_{2} \mathrm{O}_{3} \mathrm{~S}$ 527.1004, found 527.0979.

\section{3. $\mathrm{RCM}$ reactions}

4.3.1. 10-[N-((Z)-2-Bromo-2-butenyl)- $N$-(methoxycarbonyl)amino]5-(phenylsulfonyl)-9,10-dihydro-6H-cyclohepta[b]indole (7). The second generation Grubbs catalyst $(7 \mathrm{~mol} \%$ ) was added under $\mathrm{Ar}$ to a solution of carbamate $4(100 \mathrm{mg}, 0.18 \mathrm{mmol})$ in $\mathrm{CH}_{2} \mathrm{Cl}_{2}(2.5 \mathrm{~mL})$ and the resulting mixture was heated at reflux for $2.5 \mathrm{~h}$. The reaction mixture was concentrated and the residue was chromatographed (96:4 hexanes/AcOEt) to give the title compound 7 as a yellow oil: $76 \mathrm{mg}$ (80\%); ${ }^{1} \mathrm{H}$ NMR (400 MHz) $\delta 1.49$ (dm, J=6.5 Hz, 3H), 2.55 (br, $1 \mathrm{H}), 2.65$ (br, $1 \mathrm{H}), 3.40$ (d, J=16.8 Hz, 1H), 3.78 (br s, 3H), $4.05(\mathrm{~m}, 3 \mathrm{H})$, $5.36(\mathrm{q}, J=6.5 \mathrm{~Hz}, 1 \mathrm{H}), 5.75(\mathrm{~m}, 1 \mathrm{H}), 5.88(\mathrm{~m}, 1 \mathrm{H}), 5.95(\mathrm{~m}, 1 \mathrm{H}), 7.26$ $(\mathrm{m}, 3 \mathrm{H}), 7.43(\mathrm{~m}, 2 \mathrm{H}), 7.53(\mathrm{~m}, 1 \mathrm{H}), 7.70(\mathrm{~m}, 2 \mathrm{H}), 8.23(\mathrm{~d}, J=8.0 \mathrm{~Hz}$, $1 \mathrm{H}) ;{ }^{13} \mathrm{C}$ NMR $(74.5 \mathrm{MHz}) \delta 16.3\left(\mathrm{CH}_{3}\right), 25.5\left(\mathrm{br}, \mathrm{CH}_{2}\right), 30.4\left(\mathrm{br}, \mathrm{CH}_{2}\right)$, 51.4 (br, $\mathrm{CH}), 51.9$ (br, $\left.\mathrm{CH}_{2}\right), 53.0\left(\mathrm{br}, \mathrm{CH}_{3}\right), 115.3(\mathrm{CH}), 118.7(\mathrm{br}, \mathrm{CH})$, 120.0 (C), 123.0 (br, CH), $124.1(\mathrm{CH}), 124.8(\mathrm{CH}), 124.9(\mathrm{C}), 125.0(\mathrm{C})$, $126.1(2 \mathrm{CH}), 128.9(\mathrm{CH}), 129.3(2 \mathrm{CH}), 130.3(\mathrm{CH}), 133.8(\mathrm{CH}), 136.1(\mathrm{C})$, 137.2 (br, C), 138.7 (C), 156.7 (br, CO); ESI-HRMS [M+Na] ${ }^{+}$calcd for $\mathrm{C}_{25} \mathrm{H}_{25} \mathrm{BrN}_{2} \mathrm{NaO}_{4} \mathrm{~S}$ 551.0616, found 551.0591.

4.3.2. 10-[N-((Z)-2-Iodo-2-butenyl)- $N$-(methoxycarbonyl)amino]-5(phenylsulfonyl)-9,10-dihydro-6H-cyclohepta[b]indole (8). Operating as above, from carbamate $5(0.30 \mathrm{~g}, 0.5 \mathrm{mmol})$, the title compound $\mathbf{8}$ was obtained as a yellow oil after column chromatography (96:4 hexanes/AcOEt): $0.22 \mathrm{~g}(78 \%) ;{ }^{1} \mathrm{H} \mathrm{NMR} \mathrm{(400} \mathrm{MHz,}$ major rotamer) $\delta 1.51(\mathrm{~d}, J=6.0 \mathrm{~Hz}, 3 \mathrm{H}), 2.59(\mathrm{br}, 1 \mathrm{H}), 2.74(\mathrm{br}, 1 \mathrm{H})$, 3.49 (d, $J=16 \mathrm{~Hz}, 1 \mathrm{H}), 3.71$ (d, $J=16 \mathrm{~Hz}, 1 \mathrm{H}), 3.78$ (br s, 3H), 3.99 (m, $2 \mathrm{H}), 5.25(\mathrm{q}, J=6 \mathrm{~Hz}, 1 \mathrm{H}), 5.72(\mathrm{~m}, 1 \mathrm{H}), 5.86(\mathrm{~m}, 1 \mathrm{H}), 5.95(\mathrm{~m}, 1 \mathrm{H}), 7.22$ $(\mathrm{m}, 1 \mathrm{H}), 7.29(\mathrm{~m}, 2 \mathrm{H}), 7.44(\mathrm{~m}, 2 \mathrm{H}), 7.54(\mathrm{~m}, 1 \mathrm{H}), 7.71(\mathrm{~m}, 2 \mathrm{H}), 8.23(\mathrm{~d}$, $J=8.4 \mathrm{~Hz}, 1 \mathrm{H}) ;{ }^{13} \mathrm{C}$ NMR $(74.5 \mathrm{MHz}) \delta 21.6\left(\mathrm{CH}_{3}\right), 25.6\left(\mathrm{br}, \mathrm{CH}_{2}\right), 30.9$ (br, $\left.\mathrm{CH}_{2}\right), 52.4$ (br, $\left.\mathrm{CH}\right), 53.1$ (br, $\left.\mathrm{CH}_{3}\right), 55.1$ (br, $\left.\mathrm{CH}_{2}\right), 106.9$ (br, C), 115.2 (CH), 118.6 (br, CH), 119.7 (br, C), $124.1(\mathrm{CH}), 124.8(\mathrm{CH}), 126.1$ (2CH), $126.4(\mathrm{C}), 128.9(\mathrm{CH}), 129.0(\mathrm{CH}), 129.4(2 \mathrm{CH}), 130.2(\mathrm{CH})$; 133.9 (CH), 136.1 (C), 137.2 (br, C), 138.8 (C), 156.9 (CO); ESI-HRMS $[\mathrm{M}+\mathrm{Na}]^{+}$calcd for $\mathrm{C}_{25} \mathrm{H}_{25} \mathrm{IN}_{2} \mathrm{NaO}_{4} \mathrm{~S} 599.0472$, found 599.0474 .

4.3.3. $10-[N-((Z)-2-B r o m o-2-b u t e n y l)-N$-methylamino]-5-(phenylsulfonyl)-9,10-dihydro-6H-cyclohepta[b]indole (9). Amine 6 hydrochloride ( $84 \mathrm{mg}, 0.16 \mathrm{mmol}$ ) in $\mathrm{CH}_{2} \mathrm{Cl}_{2}(2.4 \mathrm{~mL}, 0.07 \mathrm{M})$ was heated at reflux in the presence of the second generation Grubbs catalyst ( $7 \mathrm{~mol} \%$ ) for $2 \mathrm{~h}$. The reaction mixture was diluted with a saturated aqueous $\mathrm{NaHCO}_{3}$ solution $(10 \mathrm{~mL})$ and extracted with $\mathrm{CH}_{2} \mathrm{Cl}_{2}$ $(3 \times 10 \mathrm{~mL})$. The combined organic extracts were dried and 
concentrated, and the resulting residue was chromatographed (97:3 hexanes/AcOEt) to give the title compound 9 as a light brown oil: $52 \mathrm{mg}(65 \%) ;{ }^{1} \mathrm{H}$ NMR (400 MHz) $\delta 1.70(\mathrm{~d}, J=6 \mathrm{~Hz}, 3 \mathrm{H}), 2.03$ (s, $3 \mathrm{H}), 2.40(\mathrm{~m}, 1 \mathrm{H}), 2.60(\mathrm{~m}, 1 \mathrm{H}), 3.12$ and $3.22(2 \mathrm{~d}, J=14.0 \mathrm{~Hz}, 2 \mathrm{H})$, $3.95(\mathrm{~m}, 3 \mathrm{H}), 5.84(\mathrm{~m}, 3 \mathrm{H}), 7.23(\mathrm{~m}, 2 \mathrm{H}), 7.33(\mathrm{~m}, 2 \mathrm{H}), 7.46(\mathrm{~m}, 1 \mathrm{H})$, $7.62(\mathrm{~m}, 2 \mathrm{H}), 7.82(\mathrm{~d}, J=7.5 \mathrm{~Hz}, 1 \mathrm{H}), 8.17(\mathrm{~d}, J=8.0 \mathrm{~Hz}, 1 \mathrm{H}) ;{ }^{13} \mathrm{C}$ NMR (74.5 MHz) $\delta 16.6\left(\mathrm{CH}_{3}\right), 25.3\left(\mathrm{CH}_{2}\right), 25.9\left(\mathrm{CH}_{2}\right), 36.9\left(\mathrm{CH}_{3}\right), 58.5$ $(\mathrm{CH}), 63.2\left(\mathrm{CH}_{2}\right), 115.4(\mathrm{CH}), 120.8(\mathrm{CH}), 123.6(\mathrm{CH}), 124.1(\mathrm{C}), 124.3$ $(\mathrm{CH}), 125.5(\mathrm{CH}), 126.1(2 \mathrm{CH}), 126.9(\mathrm{C}), 128.6(\mathrm{CH}), 128.7(\mathrm{CH}), 128.9$ $(2 \mathrm{CH}), 131.4(\mathrm{C}), 133.5(\mathrm{CH}), 136.5(\mathrm{C}), 136.6(\mathrm{C}), 138.2(\mathrm{C})$; ESI-HRMS $[\mathrm{M}+\mathrm{H}]^{+}$calcd for $\mathrm{C}_{24} \mathrm{H}_{26} \mathrm{BrN}_{2} \mathrm{O}_{2} \mathrm{~S} 485.0892$, found 485.0873 .

4.3.4. 10-((Z)-2-Bromo-N-methyl-2-butenamido)-5-(phenylsulfonyl)-9,10-dihydro-6H-cyclohepta[b]indole (13). The second generation Grubbs catalyst ( $7 \mathrm{~mol} \%$ ) was added under Ar to a solution of amide $12(50 \mathrm{mg}, 0.09 \mathrm{mmol})$ in $\mathrm{CH}_{2} \mathrm{Cl}_{2}(2 \mathrm{~mL})$ and the resulting mixture was heated at reflux for $3 \mathrm{~h}$. The reaction mixture was concentrated and the residue was chromatographed (95:5 hexanes/AcOEt) to give the title compound $\mathbf{1 3}$ as a light brown foam: $41 \mathrm{mg}(87 \%) ;{ }^{1} \mathrm{H}$ NMR (400 MHz, major rotamer) $\delta 1.82(\mathrm{~d}, J=6.8 \mathrm{~Hz}$, $3 \mathrm{H}), 2.47(\mathrm{~s}, 3 \mathrm{H}), 2.55(\mathrm{~m}, 1 \mathrm{H}), 2.75(\mathrm{~m}, 1 \mathrm{H}), 3.90(\mathrm{~m}, 2 \mathrm{H}), 5.90(\mathrm{br} \mathrm{s}$, $1 \mathrm{H}), 5.99(\mathrm{~m}, 2 \mathrm{H}), 6.20(\mathrm{br} \mathrm{q}, J=6.8 \mathrm{~Hz}, 1 \mathrm{H}), 7.20-7.45(\mathrm{~m}, 5 \mathrm{H}), 7.52$ $(\mathrm{m}, 1 \mathrm{H}), 7.67(\mathrm{~d}, J=7.2 \mathrm{~Hz}, 2 \mathrm{H}), 8.23(\mathrm{~d}, J=8 \mathrm{~Hz}, 1 \mathrm{H}) ;{ }^{13} \mathrm{C}$ NMR (74.5 MHz) $\delta 16.3\left(\mathrm{CH}_{3}\right), 25.1\left(\mathrm{CH}_{2}\right), 28.9\left(\mathrm{CH}_{2}\right), 32.9\left(\mathrm{CH}_{3}\right), 49.3(\mathrm{CH})$, $115.6(\mathrm{CH}), 117.3(\mathrm{C}), 118.6(\mathrm{CH}), 124.4(\mathrm{CH}), 125.0(\mathrm{CH}), 126.1(2 \mathrm{CH})$, $129.1(2 \mathrm{CH}), 129.2(1 \mathrm{CH}), 130.2(\mathrm{C}), 130.7(\mathrm{CH}), 133.7(\mathrm{CH}), 136.5(\mathrm{C})$, $137.2(\mathrm{C}), 138.5(\mathrm{C}), 166.6$ (CO), one quaternary $\mathrm{C}$ not observed; ESIHRMS $[\mathrm{M}+\mathrm{H}]^{+}$calcd for $\mathrm{C}_{24} \mathrm{H}_{24} \mathrm{BrN}_{2} \mathrm{O}_{3} \mathrm{~S}$ 499.0691, found 499.0695.

\subsection{Synthesis of cyclohepta[b]indole 21}

4.4.1. 3-[1-(N-tert-Butoxycarbonyl-N-methylamino)-3-butenyl]-1(methoxymethyl)indole (18). Methylamine $(8 \mathrm{M}$ in EtOH, $1.32 \mathrm{~mL}$, $10.6 \mathrm{mmol})$ and $\mathrm{AcOH}(0.06 \mathrm{~mL}, 1.06 \mathrm{mmol})$ were successively added to a solution of aldehyde $\mathbf{1 6}^{16}(0.2 \mathrm{~g}, 1.06 \mathrm{mmol})$ in $\mathrm{CH}_{2} \mathrm{Cl}_{2}(8 \mathrm{~mL})$. After being stirred at rt overnight, the reaction mixture was diluted with $\mathrm{CH}_{2} \mathrm{Cl}_{2}(5 \mathrm{~mL})$, basified with a saturated $\mathrm{Na}_{2} \mathrm{CO}_{3}$ solution, and extracted with $\mathrm{CH}_{2} \mathrm{Cl}_{2}(3 \times 10 \mathrm{~mL})$. The organic extracts were dried and concentrated to give the crude imine. Allylmagnesium bromide ( $1 \mathrm{M}$ in $\mathrm{Et}_{2} \mathrm{O}, 1.59 \mathrm{~mL}, 1.59 \mathrm{mmol}$ ) was added under $\mathrm{Ar}$ to a cooled $\left(-78^{\circ} \mathrm{C}\right)$ solution of the above material in anhydrous THF $(25 \mathrm{~mL})$, and the mixture was stirred at rt overnight. The reaction mixture was quenched with a $10 \%$ aqueous $\mathrm{NH}_{4} \mathrm{Cl}$ solution $(10 \mathrm{~mL})$ and extracted with $\mathrm{Et}_{2} \mathrm{O}(3 \times 10 \mathrm{~mL})$. The organic extracts were dried and concentrated to give the crude secondary amine. $\mathrm{Et}_{3} \mathrm{~N}(0.85 \mathrm{~mL}$, $6.08 \mathrm{mmol})$ and $(\mathrm{Boc})_{2} \mathrm{O}(0.46 \mathrm{~g}, 2.12 \mathrm{mmol})$ were successively added to a solution of the above material in $\mathrm{MeOH}(30 \mathrm{~mL})$ and the mixture was heated at reflux for $5 \mathrm{~h}$. The solvent was removed and the residue was diluted with $\mathrm{CH}_{2} \mathrm{Cl}_{2}(30 \mathrm{~mL})$ and washed with $1 \mathrm{~N}$ $\mathrm{HCl}(2 \times 20 \mathrm{~mL})$ and brine $(2 \times 20 \mathrm{~mL})$. The organic solution was dried and concentrated and the residue was chromatographed (85:15 hexanes/AcOEt) to give carbamate $\mathbf{1 8}$ as a light brown foam: $0.29 \mathrm{~g}$ (80\%); ${ }^{1} \mathrm{H}$ NMR (300 MHz, mixture of rotamers) $\delta 1.50$ and 1.57 (2br s, 9H), 2.50 (br, 3H), $2.71(\mathrm{~m}, 2 \mathrm{H}), 3.24(\mathrm{~s}, 3 \mathrm{H}), 5.08$ (br d, $J=10.5 \mathrm{~Hz}$, $1 \mathrm{H}), 5.17(\mathrm{dm}, J=17.1 \mathrm{~Hz}, 1 \mathrm{H}), 5.43(\mathrm{~s}, 2 \mathrm{H}), 5.60$ and $5.86(2 \mathrm{br} \mathrm{m}, 2 \mathrm{H})$, $7.08(\mathrm{~s}, 1 \mathrm{H}), 7.14(\mathrm{td}, J=7.5$ and $1 \mathrm{~Hz}, 1 \mathrm{H}), 7.25(\mathrm{td}, J=7.5$ and $1 \mathrm{~Hz}, 1 \mathrm{H})$, $7.45(\mathrm{~d}, J=7.5 \mathrm{~Hz}, 1 \mathrm{H}), 7.64$ (br d, $J=7.5 \mathrm{~Hz}, 1 \mathrm{H}) ;{ }^{13} \mathrm{C}$ NMR $(75.4 \mathrm{MHz}$, mixture of rotamers) $\delta 27.9\left(\mathrm{CH}_{3}\right), 28.5\left(\mathrm{CH}_{3}\right), 35.5\left(\mathrm{CH}_{2}\right), 49.9$ and $51.5(\mathrm{CH}), 55.9\left(\mathrm{CH}_{3}\right), 77.3\left(\mathrm{CH}_{2}\right), 79.1(\mathrm{C}), 109.7(\mathrm{CH}), 115.9(\mathrm{C}), 116.8$ and $117.1\left(\mathrm{CH}_{2}\right), 119.8(\mathrm{CH}), 120.3(\mathrm{CH}), 122.7(\mathrm{CH}), 126.0(\mathrm{CH}), 128.0$ (C), $134.9(\mathrm{CH}), 136.9(\mathrm{C}), 155.9(\mathrm{C})$.

4.4.2. 3-[1-(N-tert-Butoxycarbonyl-N-methylamino)-3-butenyl]-2chloro-1-(methoxymethyl)indole (19). Operating as above, from aldehyde $17^{17}(0.3 \mathrm{~g}, 1.28 \mathrm{mmol})$ carbamate 19 was obtained as a light brown foam after chromatography (85:15 hexanes/AcOEt): $412 \mathrm{mg}$
(85\%); ${ }^{1} \mathrm{H}$ NMR (300 MHz) $\delta 1.51(\mathrm{~s}, 9 \mathrm{H}), 2.69(\mathrm{~s}, 3 \mathrm{H}), 2.82-3.08(\mathrm{~m}$, 2H), 3.28 (s, 3H), $5.04(\mathrm{dm}, J=9 \mathrm{~Hz}, 1 \mathrm{H}), 5.16(\mathrm{dm}, J=15 \mathrm{~Hz}, 1 \mathrm{H}), 5.53$ $(\mathrm{s}, 2 \mathrm{H}), 5.72-5.90(\mathrm{~m}, 2 \mathrm{H}), 7.19(\mathrm{t}, J=7.5 \mathrm{~Hz}, 1 \mathrm{H}), 7.24(\mathrm{t}, J=7.5 \mathrm{~Hz}, 1 \mathrm{H})$, 7.42 (d, $J=7.5 \mathrm{~Hz}, 1 \mathrm{H}), 7.74$ (d, $J=7.5 \mathrm{~Hz}, 1 \mathrm{H}) ;{ }^{13} \mathrm{C}$ NMR $(75.4 \mathrm{MHz})$ $\delta 28.8\left(\mathrm{CH}_{3}\right), 29.2\left(\mathrm{CH}_{3}\right), 35.5\left(\mathrm{CH}_{2}\right), 52.1(\mathrm{CH}), 56.3\left(\mathrm{CH}_{3}\right), 74.1\left(\mathrm{CH}_{2}\right)$, $79.8(\mathrm{C}), 110.1(\mathrm{CH}), 111.2(\mathrm{C}), 117.4\left(\mathrm{CH}_{2}\right), 119.8(\mathrm{CH}), 121.4(\mathrm{CH}), 123.1$ (CH), 124.9 (C), 127.5 (C), $135.4(\mathrm{CH}), 136.0$ (C), 155.7 (C); ESI-HRMS $[\mathrm{M}+\mathrm{Na}]^{+}$calcd for $\mathrm{C}_{20} \mathrm{H}_{27} \mathrm{ClN}_{2} \mathrm{NaO}_{3}$ 401.1602, found 401.1619.

4.4.3. 3-[1-(N-tert-Butoxycarbonyl-N-methylamino)-3-butenyl]-1(methoxymethyl)-2-(1-oxo-2-propenyl)indole (20). t-BuLi (1.7 M in pentane, $0.6 \mathrm{~mL}, 1.02 \mathrm{mmol}$ ) was slowly added to a solution of 2chloroindole $19(254 \mathrm{mg}, 0.67 \mathrm{mmol})$ in THF $(12 \mathrm{~mL})$ cooled at $-78^{\circ} \mathrm{C}$ and the resulting mixture was stirred at $-78^{\circ} \mathrm{C}$ for $30 \mathrm{~min}$. Acrolein $(0.13 \mathrm{~mL}, 1.92 \mathrm{mmol})$ was added and the mixture was stirred at $-78{ }^{\circ} \mathrm{C}$ for $20 \mathrm{~min}$. The reaction mixture was quenched with $10 \%$ aqueous $\mathrm{NH}_{4} \mathrm{Cl}(15 \mathrm{~mL})$ and extracted with $\mathrm{Et}_{2} \mathrm{O}(3 \times 15 \mathrm{~mL})$. The organic extracts were dried and concentrated and the resulting residue was chromatographed (1:1 hexanes/AcOEt) to give the crude carbinol. A solution of the above material in $\mathrm{CH}_{2} \mathrm{Cl}_{2}(15 \mathrm{~mL})$ was treated with $\mathrm{MnO}_{2}(0.58 \mathrm{~g}, 6.7 \mathrm{mmol})$ at rt overnight. The reaction mixture was filtered through Celite and the filtrate was concentrated to give ketone 20 as a light brown foam: $120 \mathrm{mg}(45 \%) ;{ }^{1} \mathrm{H}$ NMR (300 MHz, major rotamer) $\delta 1.47(\mathrm{~s}, 9 \mathrm{H}), 2.75(\mathrm{~s}, 3 \mathrm{H}), 2.80(\mathrm{~m}, 2 \mathrm{H})$, $3.16(\mathrm{~s}, 3 \mathrm{H}), 4.95(\mathrm{dm}, J=9 \mathrm{~Hz}, 1 \mathrm{H}), 5.15(\mathrm{dm}, J=15 \mathrm{~Hz}, 1 \mathrm{H}), 5.46(\mathrm{~d}$, $J=8.8 \mathrm{~Hz}, 1 \mathrm{H}), 5.53(\mathrm{~d}, J=8.8 \mathrm{~Hz}, 1 \mathrm{H}), 5.57(\mathrm{~m}, 2 \mathrm{H}), 6.08(\mathrm{~d}, J=9 \mathrm{H}, 1 \mathrm{H})$, $6.18(\mathrm{~d}, J=15 \mathrm{~Hz}, 1 \mathrm{H}), 6.81(\mathrm{dd}, J=15$ and $8.8 \mathrm{~Hz}), 7.22(\mathrm{t}, J=7.5 \mathrm{~Hz}, 1 \mathrm{H})$, $7.35(\mathrm{t}, J=7.5 \mathrm{~Hz}, 1 \mathrm{H}), 7.51(\mathrm{~d}, J=7.5 \mathrm{~Hz}, 1 \mathrm{H}), 7.85(\mathrm{~d}, J=7.5 \mathrm{~Hz}, 1 \mathrm{H}) ;{ }^{13} \mathrm{C}$ NMR (75.4 MHz, major rotamer) $\delta 28.8\left(\mathrm{CH}_{3}\right), 29.8\left(\mathrm{CH}_{3}\right), 36.4\left(\mathrm{CH}_{2}\right)$, $52.3(\mathrm{CH}), 56.2\left(\mathrm{CH}_{3}\right), 75.4\left(\mathrm{CH}_{2}\right), 79.9(\mathrm{C}), 111.2(\mathrm{CH}), 117.6\left(\mathrm{CH}_{2}\right)$, $118.1(\mathrm{C}), 121.7(\mathrm{CH}), 122.4(\mathrm{CH}), 124.9(\mathrm{CH}), 127.2(\mathrm{C}), 132.3\left(\mathrm{CH}_{2}\right)$, 135.0 (CH), $135.4(\mathrm{C}), 138.0(\mathrm{CH}), 139.3$ (C), 155.5 (C), 197.0 (C); ESIHRMS $[\mathrm{M}+\mathrm{Na}]^{+}$calcd for $\mathrm{C}_{23} \mathrm{H}_{30} \mathrm{~N}_{2} \mathrm{NaO}_{4} 421.2097$, found 421.2089 .

4.4.4. 10-(N-tert-Butoxycarbonyl-N-methylamino)-5-(methoxymethyl)-9,10-dihydro-5H-cyclohepta[b]indole-6-one (21). The second generation Grubbs catalyst (30 mg, $7 \mathrm{~mol} \%$ ) was added under $\mathrm{Ar}$ to a solution of ketone $\mathbf{2 0}(0.2 \mathrm{~g}, 0.50 \mathrm{mmol})$ in $\mathrm{CH}_{2} \mathrm{Cl}_{2}(30 \mathrm{~mL})$ and the resulting mixture was heated at reflux overnight. The reaction mixture was concentrated and the residue was chromatographed (9:1 hexanes/AcOEt) to give $\mathbf{2 1}$ as a pale yellow foam: $120 \mathrm{mg}$ (65\%); ${ }^{1} \mathrm{H}$ NMR (300 MHz, major rotamer) $\delta 1.54(\mathrm{~s}, 9 \mathrm{H}), 2.66(\mathrm{~s}$, $3 \mathrm{H}), 2.85-3.05(\mathrm{~m}, 2 \mathrm{H}), 3.32(\mathrm{~s}, 3 \mathrm{H}), 6.01(\mathrm{~d}, J=10.5 \mathrm{~Hz}, 1 \mathrm{H}), 6.10$ (d, $J=10.5 \mathrm{~Hz}, 1 \mathrm{H}), 6.32(\mathrm{~d}, J=11 \mathrm{~Hz}, 1 \mathrm{H}), 6.65(\mathrm{~m}, 1 \mathrm{H}), 7.18-7.30(\mathrm{~m}$, $2 \mathrm{H}), 7.44(\mathrm{t}, J=7.5 \mathrm{~Hz}, 1 \mathrm{H}), 7.56(\mathrm{~d}, J=7.5 \mathrm{~Hz}, 1 \mathrm{H}), 7.71(\mathrm{~m}, 1 \mathrm{H}) ;{ }^{13} \mathrm{C}$ NMR (75.4 MHz, major rotamer) $\delta 28.8\left(\mathrm{CH}_{3}\right), 31.7\left(\mathrm{CH}_{3}\right), 33.3$ $\left(\mathrm{CH}_{2}\right), 49.7(\mathrm{CH}), 56.4\left(\mathrm{CH}_{3}\right), 75.9\left(\mathrm{CH}_{2} \mathrm{O}\right), 80.1(\mathrm{C}), 111.5(\mathrm{CH}), 121.9$ $(\mathrm{CH}), 122.2(\mathrm{CH}), 123.6(\mathrm{C}), 126.4(\mathrm{C}), 127.6(\mathrm{CH}), 134.8(\mathrm{CH}), 139.4$ (CH), 140.2 (C), 155.5 (C), 185.4 (C). One quaternary $\mathrm{C}$ was not observed; ESI-HRMS calcd for $\mathrm{C}_{21} \mathrm{H}_{26} \mathrm{~N}_{2} \mathrm{O}_{4}$ 370.1892, found 370.1910 .

4.4.5. 5-(Methoxymethyl)cyclohepta[b]indol-6-one (22). Yellow amorphous solid. ${ }^{1} \mathrm{H}$ NMR $(400 \mathrm{MHz}) \delta 3.37(\mathrm{~s}, 3 \mathrm{H}), 6.52(\mathrm{~s}, 2 \mathrm{H}), 7.01$ (m, 1H), 7.24-7.38 (m, 2H), $7.42(\mathrm{tm}, J=8 \mathrm{~Hz}, 1 \mathrm{H}), 7.62(\mathrm{tm}, J=8 \mathrm{~Hz}$, $1 \mathrm{H}), 7.75(\mathrm{~d}, J=8 \mathrm{~Hz}, 1 \mathrm{H}), 8.12(\mathrm{~m}, 2 \mathrm{H}) ;{ }^{13} \mathrm{C} \mathrm{NMR}(100.5 \mathrm{MHz}) \delta 56.2$ $\left(\mathrm{CH}_{3}\right), 75.6\left(\mathrm{CH}_{2}\right), 112.2(\mathrm{CH}), 120.8(\mathrm{CH}), 122.7(\mathrm{CH}), 124.9(\mathrm{CH})$, $125.1(\mathrm{C}), 126.0(\mathrm{C}), 128.4(\mathrm{CH}), 129.3(\mathrm{CH}), 135.3(\mathrm{CH}), 138.0(\mathrm{CH})$, 140.3 (C), 140.5 (C), 179.7 (C); ESI-HRMS calcd for $\mathrm{C}_{15} \mathrm{H}_{13} \mathrm{NO}_{2}$ 239.0946, found 239.0944 .

\subsection{Heck cyclizations}

4.5.1. 4-(E)-Ethylidene-2-(methoxycarbonyl)-8-(phenylsulfonyl)2,3,4,5-tetrahydro-1,5-methano-1H-azonino[4,3-b]indole (23). $\mathrm{Pd}\left(\mathrm{PPh}_{3}\right)_{4}(17 \mathrm{mg}, 0.015 \mathrm{mmol}), \mathrm{K}_{3} \mathrm{PO}_{4}(96 \mathrm{mg}, 0.45 \mathrm{mmol})$, 
phenol (3.5 mg, $0.04 \mathrm{mmol})$, and $\mathrm{Et}_{3} \mathrm{~N}(0.1 \mathrm{~mL}, 0.75 \mathrm{mmol})$ were successively added to a solution of vinyl iodide $8(87 \mathrm{mg}$, $0.15 \mathrm{mmol})$ in toluene $(11 \mathrm{~mL})$, and the resulting mixture was heated at reflux for $12 \mathrm{~h}$. The reaction mixture was diluted with $\mathrm{Et}_{2} \mathrm{O}$ and washed with a saturated aqueous $\mathrm{Na}_{2} \mathrm{CO}_{3}$ solution and brine. The organic layer was dried and concentrated. The resulting residue was chromatographed (hexanes and 95:5 hexanes/EtOAc) to give the title compound $\mathbf{2 3}$ as a light brown oil: $43 \mathrm{mg}$ (65\%); ${ }^{1} \mathrm{H}$ NMR $(400 \mathrm{MHz}$, assignment aided by gHSQC, 2:1 mixture of rotamers) $\delta 1.70(\mathrm{dm}, J=6.4 \mathrm{~Hz}, 3 \mathrm{H}), 1.91$ (d, $J=13 \mathrm{~Hz}, 1 \mathrm{H}, 13-\mathrm{H}), 2.25(\mathrm{~m}, 1 \mathrm{H}, 13-\mathrm{H}), 2.94$ and 3.10 (major) $(2 \mathrm{~d}, J=13.5 \mathrm{~Hz}, 1 \mathrm{H}, 3-\mathrm{H}), 3.67$ (major) and $3.81\left(2 \mathrm{~s}, 3 \mathrm{H}, \mathrm{OCH}_{3}\right)$, 3.81 (masked, $1 \mathrm{H}, 5-\mathrm{H}$ ), 4.04 (major) and $4.17(\mathrm{~d}, J=13.5 \mathrm{~Hz}, 1 \mathrm{H}$, $3-\mathrm{H}), 5.37$ (major) and $5.42(2 \mathrm{q}, J=6.4 \mathrm{~Hz}, 1 \mathrm{H}), 5.73$ and 5.91 (major) (2 br s, 1H, 1-H), $6.05(\mathrm{~m}, 1 \mathrm{H}), 7.31(\mathrm{~m}, 1 \mathrm{H}), 7.34(\mathrm{~m}, 1 \mathrm{H})$, $7.36(\mathrm{~m}, 2 \mathrm{H}), 7.49(\mathrm{~m}, 2 \mathrm{H}), 7.67(\mathrm{~m}, 2 \mathrm{H}), 7.85(\mathrm{~d}, J=8 \mathrm{~Hz}, 1 \mathrm{H}), 8.25$ $(\mathrm{d}, J=8 \mathrm{~Hz}, 1 \mathrm{H}) ;{ }^{13} \mathrm{C}$ NMR $(74.5 \mathrm{MHz}$, assignment aided by gHSQC, major rotamer) $\delta 12.5\left(\mathrm{CH}_{3}\right), 29.3(\mathrm{C}-13), 35.7(\mathrm{C}-5), 45.1(\mathrm{C}-1)$, $45.6(\mathrm{C}-3), 52.7\left(\mathrm{OCH}_{3}\right), 115.7(\mathrm{CH}), 118.6(\mathrm{C}-7), 119.3(\mathrm{C}), 120.2$ $(\mathrm{CH}), 120.3(\mathrm{CH}), 124.5(\mathrm{CH}), 125.6(\mathrm{CH}), 126.2(\mathrm{C}), 126.3(2 \mathrm{CH})$, $129.1(2 \mathrm{CH}), 133.3(\mathrm{C}), 133.6(\mathrm{CH}), 134.8$ (C-6), 136.1 (C), 136.9 (C), 138.2 (C), 155.1 (CO); ESI-HRMS $[\mathrm{M}+\mathrm{H}]^{+}$calcd for $\mathrm{C}_{25} \mathrm{H}_{25} \mathrm{~N}_{2} \mathrm{O}_{4} \mathrm{~S}$ 449.1529 , found 449.1523 .

4.5.2. 4-(Z)-Ethylidene-2-(methoxycarbonyl)-7-(phenylsulfonyl)1,2,3,4,5,6-hexahydro-1,5-ethenoazocino[4,3-b]indole (24). $\mathrm{PPh}_{3}$ (13 mg, $0.05 \mathrm{mmol}), \mathrm{Ag}_{2} \mathrm{CO}_{3}$ (142 mg, $0.51 \mathrm{mmol}$ ), and $\mathrm{Pd}(\mathrm{OAc})_{2}$ ( $4 \mathrm{mg}, 0.017 \mathrm{mmol}$ ) were successively added to a solution of vinyl iodide 8 (98 $\mathrm{mg}, 0.17 \mathrm{mmol})$ in toluene $(9 \mathrm{~mL})$, and the resulting mixture was stirred at $80^{\circ} \mathrm{C}$ for $1 \mathrm{~h}$. The solvent was removed and the resulting residue was dissolved in $\mathrm{CH}_{2} \mathrm{Cl}_{2}(10 \mathrm{~mL})$ and washed with $\mathrm{H}_{2} \mathrm{O}(5 \mathrm{~mL})$. The organic extracts were dried and concentrated and the resulting residue was chromatographed (from cyclohexane to $94: 6$ cyclohexane $/ \mathrm{CH}_{2} \mathrm{Cl}_{2}$ ) to give $\mathbf{2 3}$ (14 mg, $19 \%$ ) and the title compound 24 as a light brown oil: $33 \mathrm{mg}$ (43\%); ${ }^{1} \mathrm{H}$ NMR ( $400 \mathrm{MHz}$, assignment aided by gCOSY and gHSQC, 2:1 mixture of rotamers) $\delta 1.58$ (major) and $1.65\left(2 \mathrm{~d}, J=6.4 \mathrm{~Hz}, 3 \mathrm{H}, \mathrm{CH}_{3}\right), 3.27$ (br $\mathrm{s}, 1 \mathrm{H}, 5-\mathrm{H}), 3.30(\mathrm{~m}, 2 \mathrm{H}, 6-\mathrm{H}), 3.70$ (major) and $3.76\left(2 \mathrm{~s}, 3 \mathrm{H}, \mathrm{OCH}_{3}\right)$, $3.72(\mathrm{~m}, 1 \mathrm{H}, 3-\mathrm{H}), 4.43$ and $4.67(2 \mathrm{~d}, J=15.2 \mathrm{~Hz}, 1 \mathrm{H}, 3-\mathrm{H}), 5.39(\mathrm{~m}$, $1 \mathrm{H}, \mathrm{CH}=$ ethylidene), 5.79 and 6.01 (major) $(2 \mathrm{~d}, J=7.6$ or $8 \mathrm{~Hz}, 1 \mathrm{H}$, 1-H), $6.16(\mathrm{t}, J=8.8 \mathrm{~Hz}, 1 \mathrm{H}, 13-\mathrm{H}), 6.30(\mathrm{~m}, 1 \mathrm{H}, 12-\mathrm{H}), 7.26(\mathrm{~m}, 2 \mathrm{H})$, $7.40(\mathrm{~m}, 2 \mathrm{H}), 7.53(\mathrm{~m}, 1 \mathrm{H}), 7.70(\mathrm{~m}, 3 \mathrm{H}), 8.20(\mathrm{~m}, 1 \mathrm{H}) ;{ }^{13} \mathrm{C} \mathrm{NMR}$ (74.5 MHz, assignment aided by gHSQC, major rotamer) $\delta 13.2$ $\left(\mathrm{CH}_{3}\right), 32.8$ (C-6), $41.0(\mathrm{C}-3), 42.2(\mathrm{C}-5), 46.5(\mathrm{C}-1), 52.8\left(\mathrm{OCH}_{3}\right)$, 114.4 (CH), $117.0(\mathrm{C}), 118.7(\mathrm{CH}), 123.0$ (CH ethylidene), $123.7(\mathrm{CH})$, $124.5(\mathrm{CH}), 126.2(2 \mathrm{CH}), 129.2(2 \mathrm{CH}), 129.5(\mathrm{C}), 132.0(\mathrm{C}-12), 133.4$ (C-13), 133.6 (CH), 134.9 (C), 135.9 (C), 138.4 (C), 139.1 (C), 156.1 (CO); ESI-HRMS $[\mathrm{M}+\mathrm{H}]^{+}$calcd for $\mathrm{C}_{25} \mathrm{H}_{25} \mathrm{~N}_{2} \mathrm{O}_{4} \mathrm{~S} 449.1529$, found 449.1527.

4.5.3. 4-(E)-Ethylidene-2-methyl-3-oxo-8-(phenylsulfonyl)-2,3,4,5tetrahydro-1,5-methano-1H-azonino[4,3-b]indole (25). $\mathrm{PPh}_{3}(6 \mathrm{mg}$, $0.024 \mathrm{mmol}), \mathrm{Pd}(\mathrm{OAc})_{2}(1 \mathrm{mg}, 0.004 \mathrm{mmol})$, proton sponge (1.7 mg, $0.008 \mathrm{mmol})$, and $\mathrm{K}_{2} \mathrm{CO}_{3}(12 \mathrm{mg}, 0.09 \mathrm{mmol})$ were successively added to a solution of vinyl bromide $13(40 \mathrm{mg}, 0.08 \mathrm{mmol})$ in toluene $(5 \mathrm{~mL})$, and the resulting mixture was heated at reflux for $20 \mathrm{~h}$. The solvent was removed and the resulting residue was dissolved in $\mathrm{CH}_{2} \mathrm{Cl}_{2}(5 \mathrm{~mL})$ and washed with $\mathrm{H}_{2} \mathrm{O}(2 \times 5 \mathrm{~mL})$. The organic extracts were dried and concentrated and the resulting residue was chromatographed (95:5 hexanes/AcOEt) to give the title compound 25 as a light brown foam: $17 \mathrm{mg}$ (50\%); ${ }^{1} \mathrm{H}$ NMR (400 MHz, assignment aided by gHSQC) $\delta 1.90(\mathrm{~d}, J=7.2 \mathrm{~Hz}, 3 \mathrm{H}), 2.11$ (dd, $J=13$ and $2 \mathrm{~Hz}, 1 \mathrm{H}, 13-\mathrm{H}), 2.60(\mathrm{dm}, J=13 \mathrm{~Hz}, 1 \mathrm{H}, 13-\mathrm{H}), 2.82(\mathrm{~s}$, $\left.3 \mathrm{H}, \mathrm{NCH}_{3}\right), 3.95(\mathrm{~m}, 1 \mathrm{H}, 5-\mathrm{H}), 4.88(\mathrm{~d}, J=6.5 \mathrm{~Hz}, 1 \mathrm{H}, 1-\mathrm{H}), 5.95$ (dd, $J=12$ and $6 \mathrm{~Hz}, 1 \mathrm{H}, 6-\mathrm{H}), 6.90(\mathrm{q}, J=7.2 \mathrm{~Hz}, 1 \mathrm{H}), 7.30-7.40(\mathrm{~m}, 4 \mathrm{H})$, $7.55(\mathrm{~m}, 3 \mathrm{H}), 7.65(\mathrm{~m}, 2 \mathrm{H}), 8.25(\mathrm{~d}, J=8 \mathrm{~Hz}, 1 \mathrm{H}) ;{ }^{13} \mathrm{C} \mathrm{NMR}(74.5 \mathrm{MHz}$, assignment aided by gHSQC) $\delta 13.9\left(\mathrm{CH}_{3}\right), 37.6(\mathrm{C}-13), 34.1\left(\mathrm{NCH}_{3}\right)$, 35.9 (C-5), 51.7 (C-1), $116.4(\mathrm{CH}), 117.0(\mathrm{CH}), 118.1(\mathrm{C}-7), 124.5(\mathrm{C})$, 124.6 (CH), $125.6(\mathrm{CH}), 126.6(2 \mathrm{CH}), 127.3(\mathrm{C}), 129.3(2 \mathrm{CH}), 130.1(\mathrm{C})$, $132.8(\mathrm{CH}), 134.0(\mathrm{CH}), 134.6$ (C-6), $134.9(\mathrm{C}), 136.4(\mathrm{C}), 138.5(\mathrm{C})$, 116.7 (CO); ESI-HRMS $[\mathrm{M}+\mathrm{H}]^{+}$calcd for $\mathrm{C}_{24} \mathrm{H}_{23} \mathrm{~N}_{2} \mathrm{O}_{3} \mathrm{~S} 419.1424$, found 419.1412 .

\section{Acknowledgements}

We thank the Ministerio de Economía y Competitividad, Spain, for financial support (project CTQ2009-07175) and the University of Barcelona for a grant to S.A.

\section{Supplementary data}

Supplementary data associated with this article can be found in the online version, at doi:10.1016/j.tet.2012.04.022.

\section{References and notes}

1. Joule, J. A. In Indoles, The Monoterpenoid Indole Alkaloids; Saxton, J. E., Ed.; Wiley: New York, NY, 1983; Vol. 25, pp 232-239.

2. Andriantsiferana, M.; Besselièvre, R.; Riche, C.; Husson, H.-P. Tetrahedron Lett. 1977, 2587-2590.

3. (a) Grierson, D. S.; Harris, M.; Husson, H.-P. Tetrahedron 1983, 39, 3683-3694; (b) Bosch, J.; Rubiralta, M.; Domingo, A.; Bolós, J.; Linares, A.; Minguillón, C.; Amat, M.; Bonjoch, J. J. Org. Chem. 1985, 50, 1516-1522; (c) Bosch, J.; Rubiralta, M.; Bolós, J. Tetrahedron 1987, 43, 391-396; (d) Salas, M.; Joule, J. A. J. Chem. Res., Miniprint 1990, 664-673; (e) Rubiralta, M.; Marco, M.-P.; Bolós, J.; Trapé, J. Tetrahedron 1991, 47, 5585-5602.

4. For a more recent approach, see Amat, M.; Checa, B.; Llor, N.; Pérez, M.; Bosch, J. Eur. J. Org. Chem. 2011, 898-907.

5. (a) Bennasar, M.-L.; Vidal, B.; Bosch, J. J. Am. Chem. Soc. 1993, 115, 5340-5341; (b) Bennasar, M.-L.; Vidal, B.; Bosch, J. J. Org. Chem. 1997, 62, 3597-3609; For the enantioselective version, see: (c) Bennasar, M.-L.; Zulaica, E.; Alonso, Y.; Bosch, J. Tetrahedron: Asymmetry 2003, 14, 469-479.

6. For general reviews, see: (a) Handbook of Metathesis; Grubbs, R. H., Ed.; WileyVCH: Weinheim, 2003; Vol. 2; (b) Deiters, A.; Martin, S. F. Chem. Rev. 2004, 104, 2199-2238.

7. For general reviews, see: (a) Bräse, S.; de Meijere, A. In Metal-Catalyzed CrossCoupling Reactions; de Meijere, A., Diederich, F., Eds.; Wiley-WCH: New York, NY, 2004; pp 217-316; (b) Zeni, G.; Larock, R. C. Chem. Rev. 2006, 106, 4644-4680.

8. For a preliminary communication of part of this work, see: Bennasar, M.-L.; Zulaica, E.; Solé, D.; Alonso, S. Synlett 2008, 667-670.

9. For the construction of polycyclic systems by sequential RCM and aryl or heteroaryl halide Heck cyclizations, see: (a) Grigg, R.; Sridharan, V.; York, M. Tetrahedron Lett. 1998, 39, 4139-4142; (b) Grigg, R.; York, M. Tetrahedron Lett. 2000, 41, 7255-7278; (c) Lautens, M.; Zunic, V. Can. J. Chem. 2004, 82, 399-407; (d) Enders, D.; Lenzen, A.; Backes, M.; Janeck, C.; Catlin, K.; Lannou, M.-I.; Runsink, J.; Raabe, G. J. Org. Chem. 2005, 70, 10538-10551; (e) Sunderhaus, J. D.; Dockendorff, C.; Martin, S. F. Org. Lett. 2007, 9, 4223-4226; (f) Ribelin, T. P.; Judd, A. S.; Akritopoulou-Zanze, I.; Henry, R. F.; Cross, J. L.; Whittern, D. N.; Djuric, S. W. Org. Lett. 2007, 9, 5119-5122.

10. (a) Rawal, V. H.; Michoud, C. Tetrahedron Lett. 1991, 32, 1695-1698; (b) Rawal, V. H.; Michoud, C.; Monestel, R. F. J. Am. Chem. Soc. 1993, 115, 3030-3031; (c) Rawal, V. H.; Iwasa, S. J. Org. Chem. 1994, 59, 2685-2686; (d) Solé, D.; Bonjoch, J.; García-Rubio, S.; Peidró, E.; Bosch, J. Chem.-Eur. J. 2000, 6, 655-665; (e) Eichberg, M. J.; Dorta, R. L.; Grotjahn, D. B.; Lamottke, K.; Schmidt, M.; Vollhardt, K. P. C. J. Am. Chem. Soc. 2001, 123, 9324-9337; (f) Mori, M.; Nakanishi, M.; Kahishima, D.; Sato, Y. J. Am. Chem. Soc. 2003, 125, 9801-9807; (g) Dounay, A. B.; Humphreys, P. G.; Overman, L. E.; Wrobleski, A. D. J. Am. Chem. Soc. 2008, 130, 5368-5377; (h) Martin, D. B. C.; Vanderwal, C. D. J. Am. Chem. Soc. 2009, $131,3472-3473$.

11. Birman, V. B.; Rawal, V. H. J. Org. Chem. 1998, 63, 9146-9147.

12. (a) Bennasar, M.-L.; Zulaica, E.; Solé, D.; Alonso, S. Chem. Commun. 2009, 3372-3374; (b) Bennasar, M.-L.; Zulaica, E.; Solé, D.; Roca, T.; García-Díaz, D.; Alonso, S. J. Org. Chem. 2009, 74, 8359-8368.

13. Bennasar, M.-L.; Solé, D.; Zulaica, E.; Alonso, S. Org. Lett. 2011, 13, 2042-2045.

14. For instance, see: (a) Ban, Y.; Yoshida, K.; Goto, J.; Oishi, T.; Takeda, E. Tetrahedron 1983, 39, 3657-3668; (b) Gràcia, J.; Casamitjana, N.; Bonjoch, J.; Bosch, J. J. Org. Chem. 1994, 59, 3939-3951; (c) Saito, M.; Kawamura, M.; Hiroya, K.; Ogasawara, K. J. Chem. Commun. 1997, 765-766.

15. Bennasar, M.-L.; Zulaica, E.; Solé, D.; Alonso, S. Tetrahedron 2007, 63, 861-866.

16. Comins, D. L.; Killpack, M. O. J. Org. Chem. 1987, 52, 104-109.

17. Hagiwara, H.; Choshi, T.; Nobuhiro, J.; Fujimoto, H.; Hibino, S. Chem. Pharm. Bull. 2001, 49, 881-886.

18. (a) Jeffery, T. Tetrahedron Lett. 1985, 26, 2667-2670; (b) Jeffery, T. Tetrahedron 1996, 52, 10113-10130. 
19. Rutherford, J. L.; Rainka, M. P.; Buchwald, S. L. J. Am. Chem. Soc. 2002, 124, 15618-15619.

20. See also: (a) Solé, D.; Urbaneja, X.; Bonjoch, J. Tetrahedron Lett. 2004, 45, 3131-3135; (b) Solé, D.; Urbaneja, X.; Bonjoch, J. Adv. Synth. Catal. 2004, 346, 1646-1650.

21. The configuration of the ethylidene substituent was established by NOESY experiments.

22. (a) Rawal, V. H.; Michoud, C. J. Org. Chem. 1993, 58, 5583-5584; (b) Feutren, S. McAlonan, H.; Montgomery, D.; Stevenson, P. J. J. Chem. Soc., Perkin Trans. 1 2000, 1129-1137.
23. Owczarczyk, Z.; Lamaty, F.; Vawter, E. J.; Negishi, E. J. Am. Chem. Soc. 1992, 114 10091-10092.

24. A seven-membered palladacycle formed by coordination of a sulfonyl oxygen atom has been proposed as a potential transition state in some Suzuki reactions: Broutin, P.-E.; Colobert, F. Org. Lett. 2005, 7, 3737-3740.

25. Miyaura, N.; Ishikawa, M.; Suzuki, A. Tetrahedron Lett. 1992, 33, 2571-2574.

26. Solé, D.; Urbaneja, X.; Cordero-Vargas, A.; Bonjoch, J. Tetrahedron 2007, 63, 10177-10184.

27. Bachman, G. B. J. Am. Chem. Soc. 1933, 55, 4279-4284 